\title{
日韓機械翻訳システムの現状分析および開発への提言
}

\author{
金泰完 ${ }^{\dagger}$ 崔杞鮮 ${ }^{\dagger \dagger}$
}

本技術資料は, 現在入手可能な日韓機械翻訳システムを対象に翻訳品質の評価を行 い, 日韓機械翻訳システムの現状および技術水準を把握, 今後の研究方向についてのい くつかの提言を行うことを目的とする. 現在, 韓国国内で発表, あるいは発売されてい る日韓機械翻訳システムの中で, 入手可能な四つの製品に対してユーザサイドからの 翻訳品質の分析と言語学的な解決範囲を把握するなめの対照言語学的誤謬分析を行う. さらに, (Choi and Kim 1996) と比較することにより日韓翻訳システムの性能向上の 度合いを比較する。これにより, 日韓機械翻訳システムの性能向上のための長期・短期 課題を考える. 本技術資料は, 対象にした各々のシステムの優劣のランク付けを目的と するものではないことをあらかじめ断っておく. 本技術資料での評価は限られた観点 からの分析に基づいたものであるからである.

キーワード： 日韓機械翻訳システム, 翻訳システム評価, 翻訳品質評価, 対照言語学的評価

\section{Analysis of Current Commercial Japanese to Korean Machine Translation Systems and Suggestions for Future Development}

\author{
TAE WAN Kim ${ }^{\dagger}$ and Key Sun ChOI ${ }^{\dagger \dagger}$
}

This Report describes the status and performance of current Janpanese-to-Korean Machine Translation Systems. And some suggestions for developing the better systems are made. This result is made by analyzing the latest version of four commercial Japanese-to-Korean Machine Translation Systems in Korea which have been produced until Feburary 1997. Declarative evaluation is executed in the view of user side to measure the translation quality. Typological evaluation is tried to probe the linguistic coverage of current commercial systems. Operational evaluation is performed in the view of user interface. And progress evaluation is executed by comparing the result with the result reported at (Choi and Kim 1996). This report does not intend to rank the relative standing of the systems. The evaluations are executed in the range of interest of this report.

KeyWords: Japanese to Korean Machine Translation System, machine translation system evaluation, Korean to Japanese Machine Translation System, declarative evaluation, typological evaluation, operational evaluation, progress evaluation

† ETRI コンピュタ\&ソフトウェアー研究所, 自然語処理研究部, Natural Language Information Processing Department, Systems Engineering Research Institute,Korea

†† 韓国科学技術院 電算学科, Department of Computer Scinece, KAIST,Korea 


\section{1 まえがき}

韓国において日本語は技術の分野のみではなく,経済などの他の分野においても英語に次ぐ 重要な言語の一つになっている.しかし，日本語が自由に操れる人は少ない。このような背景に より，機械翻訳に関する研究が韓国に紹介され始めた 80 年代の初めから日韓機械翻訳に対す る期待はかなり高い状況であった.このような期待が実り，90 年代に入り，韓国，あるいは日本 で開発された使用可能な日韓機械翻訳システム 5 種が市販されるようになった. しかし, 現在市 販されている商用日韓機械翻訳システムは, 日本語と韓国語の言語構造の類似点などによる一 般ユーザたちの高い期待とは裹腹にその翻訳品質は低いレベルにとどまっている．このような 現実を踏まえ，日韓機械翻訳システムの活性化を達成するために, 現在の日韓機械翻訳システム が持っている問題点を客観的に分析, 評価し，その問題点の在処を解明し，解決法を探す必要が ある.そのためには，現在の機械翻訳システムに対する客観的分析と評価が前提となる．本技 術資料は，四つの商用日韓機械翻訳システムを分析・評価し，技術的現象を把握，その問題点を 分析することにより今後の開発作業に有効ないくつかの提言を行うのに目的がある.このよう な努力の一環として, 筆者は (Choi and Kim 1996) を発表した. しかし，その後, 韓国国内では (Choi and Kim 1996) で評価対象にした各システムのアップグレードや新しいシステムの出現 という状況の変化があったのため, 現時点での分析・評価と (Choi and Kim 1996) で明らかに なった問題点とを比較することにより，解決された問題と未解決の問題がどのようなものであ るかを把握, 短期的解決課題と長期的解決課題の性格をより明確にする必要が出てきた. 翻訳シ ステムの評価には様々な側面からの評価が必要であり, 多様な評価法方が提案されている (Dijk 1979; White 1994; White and O'Connel 1996; 井佐原 1996). 本技術資料では (Arnold 1983) で 提示されたユーザサイドからの翻訳品質の評価といえる Declarative Evaluation, 開発側からの 評価であるといえる Typological Evaluation, 経済的立場からのシステムの効用性の評価である といえる Operational Evaluationの三つの立場からの評価とシステムの性能向上度評価といえ る Progress Evaluation を行う. 評価のための評価にならないよう，実際の生活で機械翻訳が用 いられるという状況を作るため, 評価対象文を市販されている 98 種の日本語で書かれた文庫本 から直接抽出し評価を行った.

今回の評価結果と (Choi and Kim 1996) を比較すると, 開発者側からの言語学的処理範囲の 評価といえる Typological Evaluation ではシステムによっては多少改善されたものが見られる が, 機械翻訳処理技術の最も重要な部分であるといえる翻訳技術そのものには大きな進展は見ら れない.と同時に, ユーザ側からの翻訳品質の向上も (Choi and Kim 1996) とあまり変わらない ことが明らかになった。これは今までの日韓機械翻訳システムの開発で用いられた方法である 一般の文法書と一般辞書に基づく演繹的翻訳規則および知識水準ではこれ以上の発展は期待で きないことを物語るものであると考えられる.この限界を乗り越えるためには実際の人間の言 語生活で用いられる日本語一韓国語間の大量の対訳用例集の構築とそれを用いた日本語と韓国 
表 1 韓国国内の日韓機械翻訳システム

\begin{tabular}{|c|c|c|}
\hline 製 品 名 & 開 発 者 & 動 作 環 境 \\
\hline ATLAS I /JK & $\begin{array}{l}\text { 富士通(日) } \\
\text { シスムエ学研究所 (韓) }\end{array}$ & 富士通大型コンピュータ（M series） \\
\hline $\begin{array}{c}\mathrm{J} \text {-Seoul } \\
\text { (Business Package) }\end{array}$ & 高電社 (日) & IBM 互換機、韓国語 WINDOWS95、16.MB \\
\hline $\begin{array}{l}\text { ハングルカナ } \\
\text { (Version } 3.0)\end{array}$ & チャンシンコンピュータ(韓) & IBM 互換機、韓国語 WINDOWS95、16:MB \\
\hline 名品 (Gold) & 日立情報ネットワーク(日) & IBM 互換機、韓国語 WINDOWS95、16 MB \\
\hline $\begin{array}{l}\text { オギョンバクサ } \\
\text { (version 1.52) }\end{array}$ & ユニテル(韓) & IBM 互換機、韓国語 WINDOWS95、16 MB \\
\hline
\end{tabular}

語の客観的で一貫性のある翻訳モデルの確立, 大量の用例に基づく帰納的翻訳規則および知識の 開発と蓄積が前提となる必要がある．効用性の評価といえる Operational Evaluation ではすべ てのシステムが韓国語 Windows95 で運用されるようになり，日本語原文入力ツールの支援，イ ンターネット翻訳支援などというように大きく進展したといえる.

\section{2 韓国国内の日韓機械翻訳システム}

現在, 韓国国内で市販, あるいは発表されたシステムを表 1に示す。この中で「ATLAS/JK」 は, 1990 年に実用化された初の日韓機械翻訳システムである.「ATLAS/JK」は, 富士通の ATLAS 翻訳システムを基に韓国語への変換, 生成のための文法および辞書の開発を韓国のシ ステム工学研究所が行った. ハードウェアプラットフォームは, 富士通の大型コンピュータ (M series) であった.「ATLAS/JK」の応用分野はJICST の論文抄録の翻訳であったが，現在で も韓国の研究開発情報センター (KORDIC) によりパソコン通信を通じて一般ユーザに日本の JOIS DB オンライン翻訳サービスが提供されている.

「J-Seoul」は，日本の高電社により開発された製品であり，最初は NEC PC 9800 シ リーズでしか運用できなかったが, 最近では IBM 互換機, 韓国語 WINDOWS95 でも使えるよ うになり，IBM 互換機が主流である韓国市場への進出の地盤を広めたといえる．「ハングル カナ」は韓国のチャンシンコンピュータにより開発されたもので, やはりIBM 互換機, 韓国語 WINDOWS95 上で動くようになっている。「名品」は，日本の日立情報ネットワークにより開 発されたものでIBM 互換機, 韓国語 WINDOWS95 上で動くようになっている.「オギョンバ クサ」は, 韓国のユニソフトにより開発されたもので, IBM 互換機, 韓国語 WINDOWS95 で動 くようになっている. 本技術資料ではこれら五つの製品の中で入手可能な四つのシステムを対 象に 1997 年 3 月現在最も最新バージョンである「J-Seoul Business Package」(1996.10)，「八 ングルカナ 3.0」(1997.2)，「名品 GOLD」(1997.2)，「オギョンバクサ 1.52」(1997.2) を対象に 分析を行った. 


\section{3 評価方法の考察}

\section{1 評価方法の概要}

機械翻訳システムの評価については様様翻訳品質に関する評価方法は大变難しい問題である (King 1996). その理由として，

- 評価とは本質的に難しい問題である

・ 機械翻訳の様々な使用目的によって評価基準の設定を変えなければならない

・ 評価基準の客観的な設定が難しい

という三つをあげることができる.しかし，このような限界を持つにも関わらず, 機械翻訳シ ステムに関する評価の必要性はシステム開発という立場からこれまで多くの研究がなされてき た.これら研究を総合してみると, 評価には大きく三つの観点が必要である (Arnold 1983).

(1) Declarative Evaluation

(2) Typological Evaluation

(3) Operational Evaluation

以上の三つの以外に開発者の立場で重要なものとして

(4) Progress Evaluation

がある。

\subsection{Declarative Evaluation}

Declarative Evaluation とは, 翻訳結果に対する理解度, 正確性, 信頼性など, ユーザ側か ら見た「翻訳品質」に関する評価であり, 表 2 に示したように三つの方法が用いられている. (Dijk 1979) では, 最も安定性が高く, 多く用いられている方法として 4 5 個のスケールを持つ r rating on intelligibility scale」法を勧めている. スケールが細かすぎると判断に苦しむこ とになり, 偏差が広がる可能性が高く, 小さすぎると弁別力が低下する恐れがあるからである.

\subsection{Typological Evaluation}

Typological Evaluation とは, 翻訳システムの言語学的側面からの解決範囲, すなわち, シス テム開発者側からの評価であるといえる.一般的にあらゆる言語現象を網羅する Test Suite 利用し, 機械翻訳された結果からシステムの言語学的解決可能範囲を評価する. しかし，この方 法は，あらゆる言語現象を網羅する有効な Test Suite そのものを作ること自体が難しい作業で 
表 2 理解度測定 (declarative evaluation)のための代表的な三つの方法

\begin{tabular}{|c|c|c|c|c|}
\hline 区分 & 方法 & 長所 & 短所 & $\cos t$ \\
\hline $\begin{array}{l}\text { Rating on } \\
\text { Intelligibility } \\
\text { Scale }\end{array}$ & $\mid \begin{array}{l}3 \text { `10 個の基準を設け翻訳品 } \\
\text { 質により点数をつける }\end{array}$ & $\begin{array}{l}\text { ・ 付随的な準備がいらない } \\
\text { 翻訳物の主題に関する必要であるがその分 } \\
\text { 野の専門家である必要は } \\
\text { ない } \\
\text { 理解度に関する直接的な } \\
\text { 測定が可能 } \\
\text { 元の言語との対照を必要 } \\
\text { としない }\end{array}$ & $\begin{array}{l}\text { • 評価者個 人の主観が介 } \\
\text { 入しやすい }\end{array}$ & 下 \\
\hline Cloze Test & $\begin{array}{l}\text { 機械翻訳結果に対し一定間 } \\
\text { 隔ごとに単語を消し評価者に } \\
\text { 適切と思われる単語を記入さ } \\
\text { せ、人間が翻訳した翻訳結果 } \\
\text { と見比べてみる }\end{array}$ & $\begin{array}{ll}\bullet & \text { 客観的 rating } \\
\text { 評価テキストを客観的に生 } \\
\text { 成することができる }\end{array}$ & $\begin{array}{l}\text { - 翻訳物の内容に関する専 } \\
\text { 門的知識が必要 } \\
\text { - 元の言語との対照が綿密 } \\
\text { に行われる必要がある }\end{array}$ & 中 \\
\hline $\begin{array}{l}\text { Multiple } \\
\text { choice } \\
\text { questionnair }\end{array}$ & $\begin{array}{l}\text { 翻訳物に対する理解度が計 } \\
\text { れる問題をマークシート形式 } \\
\text { で出題し、評価者が翻訳 結 } \\
\text { 果を読んだ後で問題を解くよ } \\
\text { うさせ、点数化する(TOEFL } \\
\text { の試験と同じ) }\end{array}$ & $\mid \begin{array}{l}\bullet \text { 情報の伝達度を測定する } \\
\text { のに便利 } \\
\text { 客観的 }\end{array}$ & $\begin{array}{l}\text { - 出題困難 } \\
\text { - 翻訳物の内容に関する十 } \\
\text { 分な專門的知識が必要 }\end{array}$ & 上 \\
\hline
\end{tabular}

あること, Test Suite で実験しようとする任意の言語現象についてのシステムの動作が実際のテ キストでは他の言語現象と複合的に現れるため同一言語現象について均一的に動作するという 保障がないのが問題点として指摘されている (King 1996; Arnold 1983).

\subsection{Operational Evaluation}

Operational Evaluation とは, 特定のユーザが特定のシステムを使うことにより得られる 経済的利益という観点からの評価であり，ユーザの機械翻訳システムの利用目的, 経済性によっ て評価結果は大きく異なる.例えば, Browsability を重視するユーザは満足している機械翻訳シ ステムでも Linguistic Accuracyを重視するユーザにとってはとても使えないといった評価が 下される場合もあり得る.また, 組織の使用目的, 要求環境, 維持補修費用, 拡張可能性, 速度な ど様々な観点からの評価が必要である.

\subsection{Progress Evaluation}

Declaraive Evaluation, Typological Evaluation, Operational Evaluation が現在のシステム の状況を評価するものであるとすれば Progress Evaluation は一つのシステムに対する通時的発 


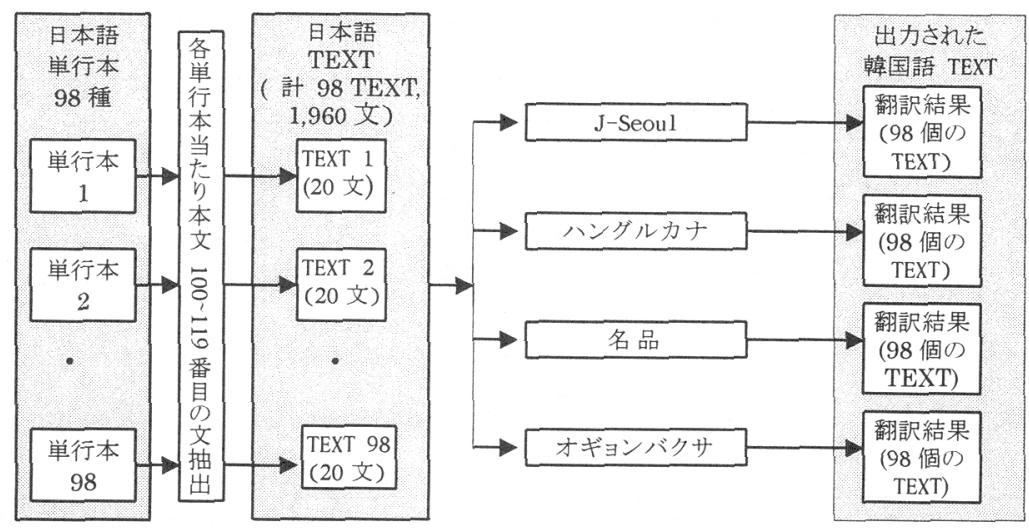

図 1 日本語標本テキストの選定および韓国語翻訳テキストの作成

展段階を把握するためのものである。これは,システム開発のそれぞれの段階で評価を行い, 問 題点および解決法を見出そうとするものである.

\section{4 評価の準備および方法}

\section{1 日本語標本テキストの選定および韓国語翻訳テキストの作成}

評価のための評価ではなく, 翻訳システムが実際の生活で使われている状況に近い状態で分 析・評価をするために評価対象文を実際市販されている 98 種の日本語で書かれた文庫本から直 接抽出し, 評価を行った (図 1参照).日本で刊行された 98 種の文庫本の本文中 100 番目の文か ら 119 番目の文までの各 20 個ずつの文を OCR 用いてテキストデータに落とし込み, 脱字や 誤字を人間が修正した 1960 個の文 $(98 \mathrm{TEXT} \times 20$ 文/TEXT=1960 文) を対象に四つの機械翻 訳システムを用い, システムごとに機械翻訳文を抽出した、各機械翻訳システムは翻訳結果とし てそれぞれ 98 個の韓国語テキストを出力する（日本語原文の抽出に使用した 98 種の文庫本の 目録は (Choi and Kim 1996) を参照) 。

\subsection{Declarative Evaluation}

本技術資料では (Dijk 1979) で推奨する”rating on intelligibility scale" 法を用いる. 互いに 関連性を持つと考えられる次の三つの項目から六つのスケールを持つ基準表を作成したそその 具体的内容を表 3 に示す。

- テキスト全体に対する理解度

・テキストを構成する文それぞれに対する評価

- 後編集の量 
表 3 Declarative Evaluation の"rating on intelligibility scale"のための評価基準表

\begin{tabular}{|c|c|}
\hline 点数 & 基準 \\
\hline 5 & $\begin{array}{l}\text { • テキスト全体の意味が明確である } \\
\text { • テキストを構成する各々の文の意味も明確である } \\
\text { ・後編集を必要としない }\end{array}$ \\
\hline 4 & $\begin{array}{l}\text { ・テキスト全体の意味がほぼ明確である } \\
\text { ・テキストを構成する各々の文の意味は不明確なところが若干ある(10〜20\%) } \\
\text { ・後編集が若干必要 }\end{array}$ \\
\hline 3 & $\begin{array}{l}\text { - テキスト全体の意味は何回か読み返すと理解可能 } \\
\text { • テキストを構成する各々の文の意味が不明確なところがかなりある }\left(20^{2} 40 \%\right) \\
\text { ・後編集がかなり必要 }\end{array}$ \\
\hline 2 & $\begin{array}{l}\text { • テキスト全体の意味を何回も読み返した後でやっと推測を通じて意味を推測することができる } \\
\text { • テキストを構成する各々の文の意味が何回読んでもはっきりしないところが多い(40〜60\%) } \\
\text { • 後編集ができないほどである }\end{array}$ \\
\hline 1 & $\begin{array}{l}\text { • 何回読んでも理解できない。しかし、完全なナンセンスではないが翻訳 結果文に現れた主なキーワ } \\
\text { 一ドによってテキストのテーマが何であるかは分かる }\end{array}$ \\
\hline 0 & • 全く理解できない \\
\hline
\end{tabular}

機械翻訳システムから出力された計 392 個 (4つのシステム $\times 98$ 個の日本語テキスト $=392$ 個の韓国語テキスト)の韓国語テキスト各システムごとの翻訳文の評価には少なくとも 1 週間 の間をおいて評価を行った. 間をおかず評価作業を続けた場合, 前回の評価の点数が記憶され評 価に影響を与えやすく，点数が甘かったり辛かったりするからである.

\subsection{Typological Evaluation 方法}

Typological Evaluation のためには，日本語の文法的, 語法的言語現象が韓国語の翻訳にど のような影響を与えるかを検討する必要がある. Typological Evaluation の典型的方法は, Test Suite を用いる方法であるが, 3.3 で述べたように様々な問題点を持つ. 本技術資料ではより現実 的な分析・評価のために Test Suite を用いず, 実生活で用いられる日本語標本テキストと韓国語 翻訳結果テキストを用い図 2 のような方法で評価を行った結果, 表 6 の誤謬の内訳に見られるよ うな結果が得られた。

Typological Evaluation には日本語原文テキストを基準に 20 個のテキスト（20 テキストメ 20 の文/テキスト $=400$ 文），対応する韓国語翻訳文テキストを基準に 80 個のテキスト（日本語 原文 20 のテキスト $\times$ 四つのシステム二韓国語 80 のテキスト； 80 テキスト $\times 20$ の文=1600 文) のみを用いた，その理由を次に示す。 
図 3 のように一般的日韓翻訳システムの 翻訳手順により翻訳誤謬のバタンを大別し、それぞれの誤謬の バタンで発生する可能性のある誤謬を予測する。

日本語の原文テキスト一個は四つの機械翻訳システムによって四つの韓国語翻訳テキストが生成され る。したがって、日本語テキスト一個は対応する四つの Declarative Evaluation 点数を持つことにな ろ:この四つの Declarative Evaluation 点数を平均し一番低い点数から順番に日本語の原文テキスト とそれに対応する韓国語翻訳テキストを対照しながら分析していく。最も低い点数から順番に分析を行う 理由は低い得点をマークしたテキストほど翻訳誤謬が多く、結果的に Typological Evaluationの価值 が高いからである。

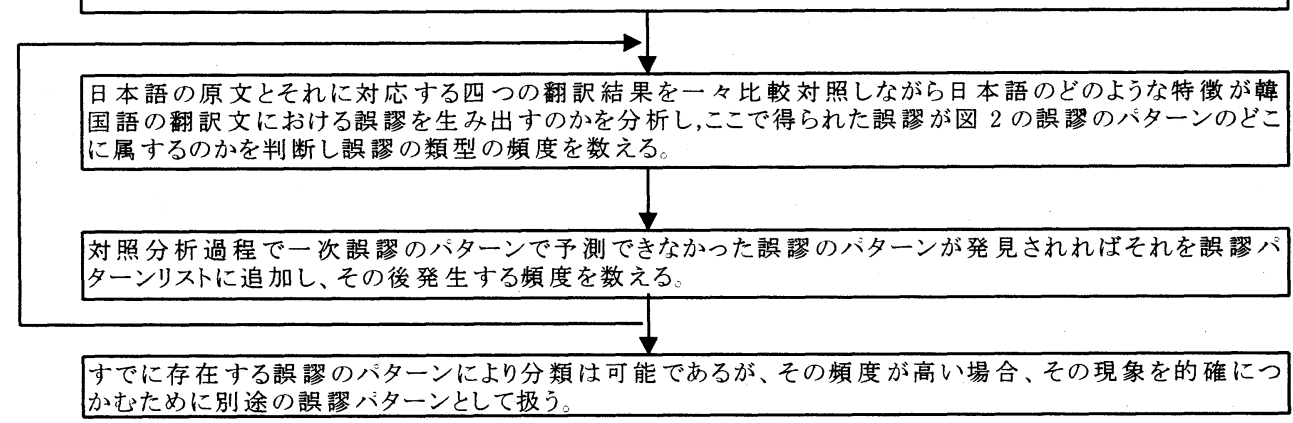

図 2 Typological Evaluation 方法



図 3 日韓機械翻訳システムの一般的誤謬

一. Declarative Evaluation が低い順に Typological Evaluation を実施した結果, 日本語原文 テキストを基準に 12 番目のテキストを分析した後から 20 番目のテキストまで新しい䛊 謬のパターンが発見されず, 誤謬のパターンの度数のみが増加した. 誤謬のパターンの度 数も誤謬パターン別の度数とほぼ同じ比率で増加した.このような観察結果に対する信 頼度を検証するために任意に 20 個の韓国語テキストを選び日本語原本テキストと比較分 析した. その結果同じ結論を得ることができた.

二. 分析の客観性を保つために, 一人の人間が評価を担当する必要があるが, 分析の量が多く, 個人の能力の限界を超えている. 
表 4 Declarative Evaluation 結果

\begin{tabular}{|c|c|c|c|c|c|c|c|c|c|c|c|c|}
\hline 区分 & \multicolumn{3}{|c|}{$\begin{array}{c}\mathrm{J} \text {-Seoul } \\
\text { Business Package }\end{array}$} & \multicolumn{3}{|c|}{ ハングルカナ 3.0} & \multicolumn{3}{|c|}{ 名品 GOLD } & \multicolumn{3}{|c|}{ オギョンバクサ 1.52} \\
\hline 評価者 & $\mathrm{A}$ & $\mathrm{B}$ & $\mathrm{C}$ & $\mathrm{A}$ & $\mathrm{B}$ & C & A & B & $\mathrm{C}$ & $\mathrm{A}$ & $B$ & C \\
\hline 総得点 & 289 & 283 & 275 & 283 & 277 & 275 & 239 & 235 & 228 & 194 & 187 & 186 \\
\hline 平均 & 2.95 & 2.89 & 2.81 & 2.89 & 2.83 & 2.81 & 2.43 & 2.40 & 2.33 & 1.98 & 1.91 & 1.90 \\
\hline 総平均 & \multicolumn{3}{|c|}{2.88} & \multicolumn{3}{|c|}{2.84} & \multicolumn{3}{|c|}{2.39} & \multicolumn{3}{|c|}{1.93} \\
\hline
\end{tabular}

\subsection{Operational Evaluation}

3.4 で見たように, Operational Evaluation は, ユーザの使用目的によって違うので客観的な 評価が困難である。したがって, 本技術資料では, Operational Evaluation に関しては, 対象 とした四つの日韓機械翻訳システムのユーザインターフェスという側面からの評価のみを行う ことにした.

\subsection{Progress Evaluation}

Progress Evaluation とは, 本来一つのシステムが発展していく各段階において各段階毎に問 題点の分析および性能向上のための評価を指す. 対象とするシステムについて十分な知識を持 つ開発者でないと客観的な評価が不可能である.さらに, 本技術資料は今回対象とした四つのシ ステムのそれぞれに対して開発戦略を立てるためのものではないため一年前に行った日韓機械 翻訳システム分析 (Choi and Kim 1996) での結果を基に, 誤謬パターンの変化, 誤謬パターンの 頻度の変化などを比べることにより日韓機械翻訳システム全般という観点からその向上の度合 いを分析した。

\section{5 評価の実施および結果分析}

\subsection{Declarative Evaluation}

評価結果は表 4の通りである. 最も高い点数をマークしたのは 2.88 点であり，これは翻訳結 果を何回か繰り返し読んだ後, 若干の推測を交えれば全体の意味が把握できるといったレべルで ある。

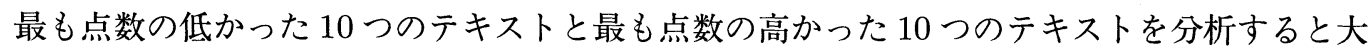
変興味深い事実が発見された. 表 5 で見られるように該当テキストのジャンル, 文体, 文の長さ， 漢字使用率, 平仮名使用率, 片仮名使用率を比較すると

一、翻訳品質は文の長さにあまり影響されない。

二．漢字使用率が高く平仮名使用率が低いほど翻訳品質が良い，

三. 翻訳する文のジャンルよりは文体に翻訳品質はもっと影響される. 
表 5 最高および最低 10 位の翻訳品質テキストリスト

\begin{tabular}{|c|c|c|c|c|c|c|c|}
\hline \begin{tabular}{|l|} 
内 \\
訳
\end{tabular} & 出典 & ジャン ル & 文体 & $\begin{array}{c}\text { 字数/ } \\
\text { 文 }\end{array}$ & $\begin{array}{l}\text { 漢字 } \\
\text { 比率 }\end{array}$ & $\begin{array}{c}\text { 平仮名 } \\
\text { 比率 }\end{array}$ & $\begin{array}{c}\text { 片仮名 } \\
\text { 比率 }\end{array}$ \\
\hline 翻 & (36)『金融入門』 & 説明文 & 乾燥体 & 46.3 & 0.43 & 0.46 & 0.03 \\
\hline 訳 & (53)『日本社会はどこ一行く一批判的考察 -』 & 論説文 & 乾燥体 & 51.9 & 0.41 & 0.47 & 0.04 \\
\hline 品 & (45)『本の枕草紙』 & 記事文 & 乾燥体 & 38.2 & 0.73 & 0.02 & 0.04 \\
\hline 質 & (5t)『日本の農業』 & 報告文 & 乾燥体 & 57.3 & 0.43 & 0.46 & 0.02 \\
\hline 結 & |(72)『先端技術と日本経済』 & 説明文 & 乾燥体 & 58 & 0.43 & 0.42 & 0.09 \\
\hline 果 & (82)『天気情報の見方』 & 説明文 & 乾燥体 & 52.2 & 0.41 & 0.48 & 0.02 \\
\hline 上 & (6)『病気と栄養』 & 説明文 & 乾燥体 & 51.3 & 0.39 & 0.47 & 0.03 \\
\hline 位 & (19)『ハイテク污染』 & 報告文 & 乾燥体 & 65 & 0.42 & 0.36 & 0.12 \\
\hline \multirow[t]{3}{*}{10} & (32)『変わる消費者、変わる商品』 & 報告文 & 乾燥体 & 47.3 & 0.32 & 0.53 & 0.09 \\
\hline & (61)『男の座標軸、企業から家庭・社会へ』 & 報告文 & 乾燥体 & 70 & 0.46 & 0.44 & 0.02 \\
\hline & & & & 53.8 & 0.44 & 0.41 & 0.05 \\
\hline 翻 & (69)『性教育は、いま』 & 論説文 & 散文体 & 27.5 & 0.17 & 0.74 & 0.01 \\
\hline 訳 & (54)『日本語に探る古代信仰ーフェティシズムから新道まで』 & 説明文 & 散文体 & 95.3 & 0.37 & 0.43 & 0.05 \\
\hline 品 & (5)『物 理 学とは何だろうか (上)』 & 説明文 & 散文体 & 67.4 & 0.29 & 0.58 & 0.07 \\
\hline 質 & (21)『異人論－民俗社会の心性』 & 論説文 & 散文体 & 71.7 & 0.36 & 0.49 & 0.07 \\
\hline 結 & (2)『愛と美と文学 -わが回想一』 & 伝記文 & 散文体 & 67.8 & 0.40 & 0.52 & 0.00 \\
\hline 果 & (62)『ママとババの戦 争』 & 伝記文 & 散文体 & 58.3 & 0.25 & 0.64 & 0.04 \\
\hline 下 & (29)『会社は誰のものか』 & 記事文 & 散文体 & 62.5 & 0.27 & 0.52 & 0.11 \\
\hline 位 & (16)『義民が駆ける』 & 小説 & 散文体 & 36.3 & 0.33 & 0.61 & 0.00 \\
\hline \multirow[t]{3}{*}{10} & (14)『冤罪の構図』 & 小説 & 散文体 & 30.8 & 0.28 & 0.59 & 0.04 \\
\hline & (4)『ブルターニュへの旅 -フランス文化の基層を求めてー』 & 紀行文 & 散文体 & 50 & 0.22 & 0.62 & 0.07 \\
\hline & & & & 56.8 & 0.29 & 0.57 & 0.05 \\
\hline
\end{tabular}

ことが分かった. 特に, 著者が形式に束縛されず自由に書いた散文のテキストが比較的低い点数 をマークし, 著者が丁重な表現を用い, 形式に拘った固い表現の多いテキストは比較的高い得点 をもらった。

\subsection{Typological Evaluation}

分析結果を表 6 に示す. 分析を行うにあたって韓国語翻訳文の誤謬がどのシステムモジュー ルで発生したかについてはそれぞれのシステムの開発者でない限り明確に特定することはでき ないため,ここでは対照言語学的立場から日本語の言語的特徴を中心にできる限り客観的に分 析を行おうと努力した. ただし, 本来評価の持つ難しさから若干の判断誤謬もあり得る.しかし， 全体的に見るとほとんど正確であるといってよい。評価には多くの時間が費やされた. 特に，あ る誤謬が発生した時, その原因を突き止めるのに大变とまどった. 例えば, 韓国語翻訳文で誤謬 が発見されたとき, それが未登録語による分析誤謬なのか, 翻訳単位認識誤謬による間違いなの か判断に迷った.このような場合, 常識的判断により, 当然登録されるべき単語について䜋謬が 発生した場合は分析誤謬として, そうでない場合は, 未翻訳として処理した. 以下, 誤謬の具体 ・例を示す. 
表 6 Typological Evaluation 結果

\begin{tabular}{|c|c|c|c|c|c|c|c|c|c|c|c|}
\hline \multirow[t]{2}{*}{\begin{tabular}{|l} 
誤 謬の \\
内訳
\end{tabular}} & \multirow[t]{2}{*}{ 詳細 } & \multicolumn{2}{|c|}{$\begin{array}{c}\text { J-Seoul } \\
\text { (Business } \\
\text { Package } \\
, 1996.10 \text { ) }\end{array}$} & \multicolumn{2}{|c|}{$\begin{array}{c}\text { ハングルカナ } \\
3.0 \\
(1997.3)\end{array}$} & \multicolumn{2}{|c|}{$\begin{array}{c}\text { 名品 } \\
\text { (GOLD, 19973) }\end{array}$} & \multicolumn{2}{|c|}{$\begin{array}{l}\text { オギョンバクサ } \\
1.52 \\
(1997.3)\end{array}$} & \multirow[t]{2}{*}{ 総計 } & \multirow{2}{*}{$\begin{array}{c}\text { 総比率 } \\
(\%)\end{array}$} \\
\hline & & $\begin{array}{l}\text { 誤謬 } \\
\text { の数 } \\
\end{array}$ & $\begin{array}{l}\text { 比率 } \\
(\%)\end{array}$ & $\begin{array}{l}\text { 誤謬 } \\
\text { の数 }\end{array}$ & $\begin{array}{c}\begin{array}{c}\text { 比率 } \\
(\%)\end{array} \\
\end{array}$ & $\begin{array}{l}\text { 諤謬 } \\
\text { の数 }\end{array}$ & $\begin{array}{l}\begin{array}{c}\text { 比率 } \\
\text { (\%) }\end{array} \\
\end{array}$ & $\begin{array}{l}\text { 誤謬 } \\
\text { の数 }\end{array}$ & $\begin{array}{c}\text { 比率 } \\
(\%)\end{array}$ & & \\
\hline 未翻訳 & 未翻訳 & 128 & 14.3 & 118 & 11.2 & 147 & 11.5 & 327 & 19.9 & 720 & 14.8 \\
\hline \multirow{2}{*}{\begin{tabular}{|l|} 
分析 \\
誤謬
\end{tabular}} & 翻訳単位認識誤謬 & 115 & 12.8 & 126 & 12.0 & 217 & 16.9 & 332 & 20.2 & 790 & 16.2 \\
\hline & 品詞判定誤謬 & 17 & 1.9 & 53 & 5.1 & 24 & 1.9 & 86 & 5.2 & 180 & 3.7 \\
\hline \multirow{16}{*}{$\begin{array}{l}\text { 多義性 } \\
\text { 誤謬 }\end{array}$} & 動詞の多義性 & 82 & 9.2 & 98 & 9.3 & 153 & 11.9 & 94 & 5.7 & 427 & 8.8 \\
\hline & 名詞の多義性 & 60 & 6.7 & 91 & 8.7 & 94 & 7.3 & 58 & 3.5 & 303 & 6.2 \\
\hline & 形容詞の多義性 & 6 & 0.7 & 4 & 0.4 & 9 & 0.7 & 1 & 0.1 & 20 & 0.4 \\
\hline & 形容動詞の多義性 & 5 & 0.6 & 2 & 0.2 & 4 & 0.3 & 0 & 0.0 & 11 & 0.2 \\
\hline & 副詞の多義性 & 26 & 2.9 & 37 & 3.5 & 19 & 1.5 & 10 & 0.6 & 92 & 1.9 \\
\hline & 連体詞の多義性 & 2 & 0.2 & 8 & 0.8 & 8 & 0.6 & 0 & 0.0 & 18 & 0.4 \\
\hline & 接続詞の多義性 & 5 & 0.6 & 4 & 0.4 & 7 & 0.5 & 2 & 0.1 & 18 & 0.4 \\
\hline & 数詞の多義性 & 13 & 1.5 & 7 & 0.7 & 8 & 0.6 & 93 & 5.7 & 121 & 2.5 \\
\hline & 「が」の多義性 & 15 & 1.7 & 23 & 2.2 & 4 & 0.3 & 6 & 0.4 & 48 & 1.0 \\
\hline & 「で」の多義性 & 11 & 1.2 & 35 & 3.3 & 19 & 1.5 & 45 & 2.7 & 110 & 2.3 \\
\hline & 「と」の多義性 & 34 & 3.8 & 37 & 3.5 & 39 & 3.0 & 48 & 2.9 & 158 & 3.2 \\
\hline & 「に」の多義性 & 47 & 5.3 & 52 & 5.0 & 68 & 5.3 & 48 & 2.9 & 215 & 4.4 \\
\hline & 「の」の多義性 & 30 & 3.4 & 36 & 3.4 & 14 & 1.1 & 32 & 1.9 & 112 & 2.3 \\
\hline & ほかの助詞(的表現) & 27 & 3.0 & 18 & 1.7 & 24 & 1.9 & 25 & 1.5 & 94 & 1.9 \\
\hline & 「よう」の多義性 & 9 & 1.0 & 10 & 1.0 & 4 & 0.3 & 9 & 0.5 & 32 & 0.7 \\
\hline & 受け身/可能/自発 & 3 & 0.3 & 4 & 0.4 & 4 & 0.3 & 3 & 0.2 & 14 & 0.3 \\
\hline \multirow{5}{*}{\begin{tabular}{|l|} 
対訳語 \\
選定 \\
誤謬
\end{tabular}} & 不自然な否定表現 & 5 & 0.6 & 7 & 0.7 & 16 & 1.2 & 13 & 0.8 & 41 & 0.8 \\
\hline & 不自然な受け身表現 & 8 & 0.9 & 16 & 1.5 & 4 & 0.3 & 5 & 0.3 & 33 & 0.7 \\
\hline & 不自然な使役表現 & 0 & 0.0 & 9 & 0.9 & 8 & 0.6 & 2 & 0.1 & 19 & 0.4 \\
\hline & 不自然な受注表現 & 3 & 0.3 & 7 & 0.7 & 5 & 0.4 & 2 & 0.1 & 17 & 0.3 \\
\hline & 不自然な対訳語 & 109 & 12.2 & 121 & 11.5 & 165 & 12.9 & 71 & 4.3 & 466 & 9.6 \\
\hline \multirow{7}{*}{\begin{tabular}{|l|} 
韓国語 \\
生成 \\
誤謬
\end{tabular}} & 状態/動作 & 23 & 2.6 & 19 & 1.8 & 27 & 2.1 & 30 & 1.8 & 99 & 2.0 \\
\hline & テンス & 13 & 1.5 & 22 & 2.1 & 17 & 1.3 & 12 & 0.7 & 64 & 1.3 \\
\hline & 慣用表現 & 2 & 0.2 & 8 & 0.8 & 3 & 0.2 & 6 & 0.4 & 19 & 0.4 \\
\hline & 定型表現 & 4 & 0.4 & 8 & 0.8 & 4 & 0.3 & 2 & 0.1 & 18 & 0.4 \\
\hline & 韓国語冠形形語尾の生成 & 18 & 2.0 & 4 & 0.4 & 15 & 1.2 & 135 & 8.2 & 172 & 3.5 \\
\hline & \begin{tabular}{|l|l} 
韓国語綴り \\
\end{tabular} & 68 & 7.6 & 57 & 5.4 & 121 & 9.4 & 124 & 7.5 & 370 & 7.6 \\
\hline & 記号前の終止形表現 & 7 & 0.8 & 8 & 0.8 & 32 & 2.5 & 24 & 1.5 & 71 & 1.5 \\
\hline 総計 & & 895 & 100.0 & 1049 & 100.0 & 1283 & 100.0 & 1645 & 100.0 & 4872 & 100.0 \\
\hline
\end{tabular}

\section{未翻訳}

翻訳されずそのままの日本語が翻訳結果文に出力されている場合を未翻訳誤謬と分類した.

(原文) 自身がない人

(翻訳結果) mauleui わんぱく aesongidul

(正しい翻訳) mauleui jangnankuroki aesongidul 


\section{分析誤謬}

日本語を韓国語に翻訳する時,一般的に同じ単位の韓国語に対応する翻訳単位を想定するこ とができる．このような単位を正確に抽出できなかった場合は翻訳単位認識誤謬とした．また， 翻訳単位は正しくても品詞決定の段階で誤謬が発生し, 誤った翻訳結果が得られた場合には品詞 判定誤謬とした.

翻訳単位認識誤謬の例

(原文）自信がない人

(翻訳結果) jasin irado duleo $\operatorname{saram}($ 自信 がない 人)

(正しい翻訳) jasini eobnun saram

(原文)

いつもこもっているのだった

(翻訳結果)

eonjena o dulgo itnun geotida

$$
\text { (いつもこもつている のだった) }
$$

(正しい翻訳) eonjena jaukhan geotieotda

品詞判定誤謬の例

(原文)

当然の扱いではあるが

(翻訳結果) dangyeoneui chooigubhae iginun hajiman(verb)

(正しい翻訳) dangyeoneui chooigubikinun hajiman(noun)

(原文） 一定ではない

(翻訳結果) iljeongi anida(noun)

(正しい翻訳) iljeonghaji anta(adjective)

\section{分析誤謬の考察}

分析鿁謬として判定されたもののほとんどは日本語の仮名文字列で発生している.このよう な傾向は四つのシステムで共通して見られ，システムによって多少違いはあるものの四つのシス テムともに仮名文字列の分析において不安定な傾向を見せている. 分析誤謬として判定された 結果を詳しく分析すると，あるシステムでは品詞のレベルで左右接続の可能/不可能すらも検査 していないものがあった．また，「品詞判断誤謬」にはほとんどが「述語の連用形」と「連用形 の名詞的用法」，「名詞」と「形容動詞の語幹」で発生している. 日本語の場合, 形容動詞で あるか名詞であるか, また, 動詞連用形であるか動詞の連用形の名詞的用法であるかによって韓 国語への翻訳は大きく異なる. 


\section{多義性による誤謬}

翻訳単位の設定, 品詞の決定が正しく行われたのにも関わらず, 意味的に全く違った対訳語 を当ててしまった場合を多義性による䛊謬と判断した. 特に, 名詞の場合は, 韓国語には存在し ない語になっているものをも多義性誤謬として分類した. また, 助詞の場合，あるシステムは可 能性がある対訳語を” ( )"の中に複数個入れて出力している. この場合, 読む時大きな無理がなけ れば鿁謬として扱わなかった。このような場合を全部誤謬にするとほとんどの多義性を持つ助 詞が䛊謬となり，全部を䛊謬がないとすると分析の意味がなくなるためである.

誤謬の例

動詞の誤謬

(原文）食事をとる

(翻訳結果) siksalul jabda(grasp)

(正しい翻訳) siksalul hada(do)

(原文) 見直しを迫る

(翻訳結果) jaepyungkalul dagaoda(come)

(正しい翻訳) jaepyungkalul kangyohada(force to do)

名詞の誤謬

(原文)

用事でやらされるのは大いに苦手だった

(翻訳結果) geobukhan sangdae(a man difficult to manage)

(正しい翻訳) golchitgeori(difficult thing)

形容詞䛊謬

(原文)

古いしきたり

(翻訳結果) nalgun(worn-out) goanrye

(正しい翻訳) oraen(long-continued) goanrye

副詞の誤謬

(原文) くまなく案内してもらった

(翻訳結果) dduryothage(sharp distinct)

(正しい翻訳) jasehi(in detail) 


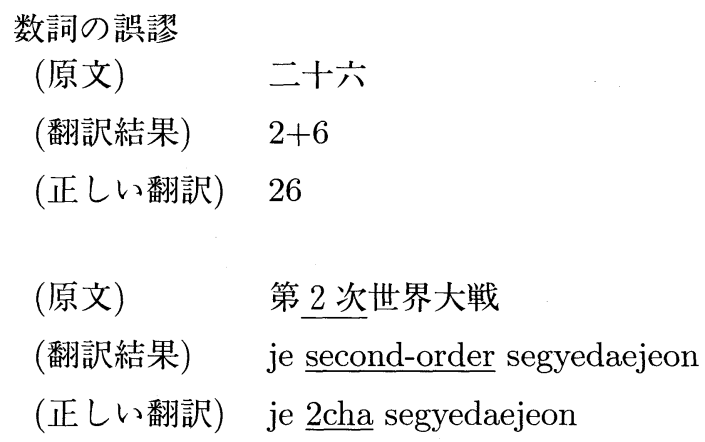

連体詞誤謬

(原文)

ある時

(翻訳結果) itnun(to be) dda

(正しい翻訳) eonu(uncertain) ddae

助詞の誤謬

(原文) 女性の増加で家庭での

(翻訳結果) junggaeso(場所)

(正しい翻訳) junggaro(原因)

受け身/可能/自発の誤謬

(原文) 密接不離の関係にあることが知られる

(翻訳結果) alryeojida(passive)

(正しい翻訳) al soo itda(can do)

「よう」の䛊謬

(原文)

考え込むようにしながら

(翻訳結果) saengkakduldorok(in order to) hamyunseo

(正しい翻訳) saengkake jamkin duti(as) hamyeonseo

\section{多義性誤謬の考察}

分析誤謬と同じく漢字表記を用いない仮名文字列で誤謬が多く見られた.さらに，漢字で表 記されている動詞の場合も多義語に関する配慮が見られず，一つの対訳しか当てられていない. これは動詞の多義性を解決する技法を用いていないことを示している. 名詞に関しては, 一般の 辞書の見出し語で最も頻繁に用いるものとして第一項目にあがっている語を機械的に対訳語と して用いているようである.したがって，文脈とあわない対訳が多く発見される．日韓翻訳の開 発の中で最も早い時期から先決課題として叫ばれていた助詞の多義性に関しては「に」と「と」 で最も誤謬が多く発見された. 特に「と」の場合は，「引用，仮定，時間的前後」などの意味をあ 
らわし，そのいずれかを決定するのが難しい。「J-Seoul」と「名品」は各システムごとに助詞の 多義性を解決するための技法を導入し，できる限り一つの対訳語だけを出していると見なされる ものの, いずれのシステムも満足のいくレベルには達していない.

\section{対訳語選定の誤謬}

翻訳単位の認識, 品詞決定が正しく行われ, その単語だけを取り出してみると意味的にも間 違っておらず，多義性の誤謬とも言えないが文全体からみて意味が通じない場合を対訳語選定の 誤謬として分類した.

不自然な否定表現

(原文) それが言えない

(翻訳結果) gugeotul malhal soo itji anta

(正しい翻訳) gugeotul malhal soo eobda

不自然な受け身表現

(原文) 八十ページも費やされているのに

(翻訳結果) sobihaejigo

(正しい翻訳) halaedoigo

不自然な使役表現

(原文) 静かめながら

(翻訳結果) joyonghi hamyunseo(自発)

(正しい翻訳) joyonghage hamyunseo(使役)

不自然なやりもらい表現

(原文) 出してみていただきたい

(翻訳結果) naeeoboa joosigo sipda

(正しい翻訳) naeeoboa joosibsio

不自然な対訳語

主に名詞に多い. 韓国語でもあるのはあるが極めてその使用例が希であり，特に文の中で不 自然であると感じられるものと「不自然なっ」に分類できないものを「不自然な対訳語誤謬」 に分類した。

(原文) 大司教のもとで

(翻訳結果) daejoogyoeui batang(foundation)eseo

(正しい翻訳) daejoogyoeui mit(beneath)eseo 
(原文) 内分泌を介して微妙に調節されている

(翻訳結果) naeboonbigyelul kiooeu(insert) …

(正しい翻訳) naeboonbigyelul maegaero hayeo(interpose) …

\section{対訳語選定の誤謬の考察}

対訳語誤謬は, 分析誤謬などに比べ比較的軽い誤謬である.しかし，これもユーザの立場から 見ると数回繰り返し読んだり原文と照らし合わせながらでないと意味を正確に把握できないと いう点で解決すべき課題であることには間違いない。

\section{韓国語生成誤謬}

表 6でも示したように上記以外の韓国語生成時の誤謬をここにまとめた.

誤謬の例

状態/動作

(原文) 見ていない

(翻訳結果) boa it(状態)ji anta

(正しい翻訳) bogo it(動作)ji anta

テンス

(原文)

来るのだった

(翻訳結果) onun geotida(現在)

(正しい翻訳) onun geotieotda(過去)

慣用表現

(原文) 口をはさむ

(翻訳結果) ibul kida(insert mouth)

(正しい翻訳) chamgyeonul hada(interfere)

定型表現

(原文)

のために

(翻訳結果) $\mathrm{ki}$ ddaemoone(reason) $/ \mathrm{ki}$ eooihaeseo(purpose)

(正しい翻訳) ki eooihaeseo(purpose)/ki ddaemoone(reason)

韓国語冠形形語尾の生成

(原文) す豆時

(翻訳結果) hanun ddae(time something is being done)

(正しい翻訳) halddae(time to do) 
韓国語綴り

韓国語の活用, 音韻縮約, 媒介母音挿入など, 韓国語の文法・用法か ら外れる場合.

\subsection{Operational Evaluation}

今回対象にした四つのシステムはューザの使用上の便宜を四るためにある程度のユーザイ ンターフェースとユーティリテイを提供している. 表 7 に四つの商用日韓機械翻訳システムが 提供する機能を示した. 四つのシステム全てが翻訳原文と翻訳結果文の編集のためのツールを 持っている. 日本語入力環境が具備されていない韓国では日本語文章作成機能と日本語文書構 成コードの内部翻訳処理コードへの変換機能が提供されなければならない. 日本語文書の新規 作成のためには「ハングルカナ」を除く他の三つのシステムは日本語入力ツールを提供してい る.「ハングルカナ」は内部処理コードが KSC5601 コードであり, 韓国語 Windows95 で提供 される KSC5601 日本語コード入力コードをそのまま使っている.コード変換機能は表 7で見ら れる通り, 各システムの内部コードへの变換機能を持っている. 翻訳処理と関連し, 未登録漢字 や片仮名を簡単にハングル音読変換を用い出力するか, あるいは該当漢字や片仮名を原文通りに 出力させるか, 翻訳処理の途中, 未登録語登録や多義性解消のための翻訳機とユーザとの相互作 用を支援すべきかなどに関するオプションを備えている. 辞書と関連し, 基本的に辞書の新規語 登録, 更新, 削除などを支援している. 翻訳処理速度は, 平均文の長さ 62.03 文字/文, 64 個の 文を翻訳する時に最も速いものが 7 秒, 最も遅いものが 2 分 10 秒程度かかった. 翻訳速度の面 では, ユーザが不便さを感じないほどにまでなっているといえそうである.

\subsection{Progress Evaluation}

一年前に行った評価と現在の評価とを比較すると, 最も目立つ発展を見せたのは「ハングル カナ」である.一年前の翻訳品質分析では「ハングルカナ」が機械翻訳というより単純な漢語 のハングル音読への変換と“について”，“において”のような表現の単純置換のレベルに過ぎ ず, 未翻訳誤謬が相当発見された.しかし, 現在の翻訳品質は未翻訳誤謬が相当減り, 翻訳結果 も相当なレベルに達している.これは, 辞書の見出し語の拡充にその発展の原因がある. 一年前 に未翻訳, 形態素分析誤謬と判定されたほとんどの語が辞書に登録されていなかったからであっ たが, 辞書にこれら未登録語を登録することにより問題が大幅に改善されたといえる. 一年前の 「ハングルカナ」が Declarative Evaluation で何回読み返しても意味が分からないといったレべ ルの低い点数 (1.95 点) をマークしたのに対し, 現在は何回か読むと全体の意味が分かるといっ たレベルにまで向上した。このような事実は, 機械翻訳における辞書の占める役割の重要さを物 語るものであるといえる。「名品」もやはり(Choi and Kim 1996) で問題として指摘された平 仮名列の分析誤謬においてある程度改善された. しかし, Declarative Evaluation の点数には変 
表 7 各システムの機能一覧表

\begin{tabular}{|c|c|c|c|c|c|}
\hline \multicolumn{2}{|c|}{ 区分 } & $\begin{array}{c}\mathrm{J}-\text { Seoul } / \mathrm{jk} \\
\text { (Business Pac) }\end{array}$ & ハングルカナ 3.0 & 名品 GOLD & オギョンバクサ 1.52 \\
\hline \multicolumn{2}{|c|}{ 内部処理コード } & KS JIS & KSC5601 & S-JIS & S-JIS \\
\hline \multirow[t]{2}{*}{ ファイル } & \begin{tabular}{|l|} 
新規ファイル \\
(日本語、韓 国 \\
語入力機能)
\end{tabular} & $\begin{array}{l}\text { J-Word と呼ぶ } \\
\text { Input Method エディ } \\
\text { ターを提供- KS JIS } \\
\text { と呼ぶ内部コードに } \\
\text { より翻訳処理 } \\
\end{array}$ & \begin{tabular}{|l|} 
韓国語ウィンドウ \\
ズ 95 の IME を利 \\
用 \\
- KSC 5601 コード \\
により翻訳処理 \\
\end{tabular} & $\begin{array}{l}-\quad \text { UnionWay と呼ぶ } \\
\text { IME を利用 } \\
- \text { S-JIS コードにより } \\
\text { 翻訳処理 }\end{array}$ & $\begin{array}{l}\text {-独自の日本語入力 } \\
\text { 編集機を提供 } \\
\text {-S-JIS により翻訳処 } \\
\text { 理 }\end{array}$ \\
\hline & コード変換 & $\begin{array}{l}\text { KS JIS, S-JIS 間相 } \\
\text { 互変換 }\end{array}$ & $\mid$\begin{tabular}{|l|} 
ファイルを開く時 \\
に S-JIS を \\
KSC5601 K変換
\end{tabular} & $\begin{array}{l}\text { JIS, EUC code を S- } \\
\text { JIS コードに変換 }\end{array}$ & $\begin{array}{l}\text { ファイルを開く時に日 } \\
\text { 本語コードを自動的 } \\
\text { に認識 }\end{array}$ \\
\hline \multirow[t]{4}{*}{ 翻訳 } & 選択翻訳 & 0 & 0 & 0 & 0 \\
\hline & 全体翻訳 & 0 & 0 & 0 & 0 \\
\hline & 一括翻訳 & 0 & 0 & 0 & 0 \\
\hline & 翻訳オプション & & \begin{tabular}{|l|} 
\\
片仮名辞書利 \\
あるいは音読 \\
変換 \\
未登録漢字出 \\
力あるいは漢字を \\
音読変換出力
\end{tabular} & 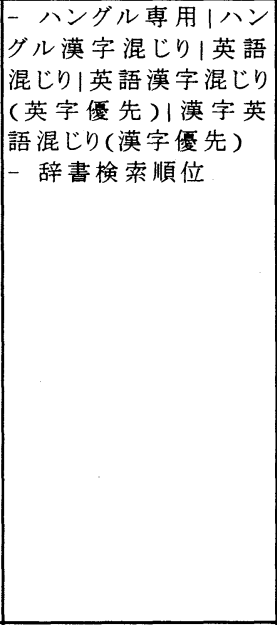 &  \\
\hline \multirow[t]{2}{*}{ 辞 書 } & 基本辞書更新 & 0 & $x$ & $x$ & 0 \\
\hline & ユーザ辞書 & 0 & 0 & 0 & 0 \\
\hline 通信 & 通信 & $x$ & $x$ & $x$ & $\begin{array}{l}\text { 日本 } の \text { PC-VAN on- } \\
1 \text { i ne 翻訳機能提供 }\end{array}$ \\
\hline \multirow[t]{3}{*}{ その他 } & モード変換 & $x$ & $x$ & $x$ & $\begin{array}{l}\text { NORMAL mode, Debug } \\
\text { Mode を分けて Debug } \\
\text { Mode ではライン単位 } \\
\text { の翻訳を行う } \\
\end{array}$ \\
\hline & 対忘文の選択 & $x$ & \begin{tabular}{|l|} 
日本語原文ある \\
いは韓国語翻訳 \\
文にカーサー置く \\
と相手言語の該 \\
当文を自動的に \\
表示
\end{tabular} & $x$ & $x$ \\
\hline & \begin{tabular}{|l|} 
インターネット \\
翻訳の支援
\end{tabular} & $\begin{array}{l}\text { “I-Seoul/JK”という } \\
\text { 別途のインターネット } \\
\text { 翻 訳 用バージョンを } \\
\text { 販売。ウェブ文章イメ } \\
\text { 一ジを維持しながら } \\
\text { ベージ単位の翻訳 } \\
\text { 可能 }\end{array}$ & $\begin{array}{l}\text { “ت゙ブリン”という } \\
\text { Drag \& Drop 基盤 } \\
\text { 翻 訳 支援ツール } \\
\text { を内臟 }\end{array}$ & & $\begin{array}{l}\text { “バーベル” という別 } \\
\text { 途のインターネット翻 } \\
\text { 訳 用バージョンを販 } \\
\text { 売 }\end{array}$ \\
\hline
\end{tabular}


化があまり見られない (一年前 - 2.37, 現在 - 2.39). その理由は (Choi and Kim 1996) でも述べ たように情報量は概念語に従属されるのに比べ概念語部分に対する誤謬には大きな改善のあと が見られなかったことによる.「J-Seoul」はあまり変化が見られない.ただ, ”記号前の終止表 現”, 助詞”と”の多義性誤謬などで改善点が見られるが Declarative Evaluation でより良い点 数をもらうには改善が不十分であった。「オギョンバクサ」は未翻訳, 分析, 多義性, 韓国語生成 の誤謬など全体に渡って多くの誤謬が見られる。これは(Choi and Kim 1996)で「ハングルカ ナ」の誤謬が未翻訳誤謬に集中していたため辞書を拡充することにより大きく翻訳誤謬が減っ たのに対し，「オギョンバクサ」は誤謬が多岐にわたっているため改善にはなお多くの努力が必 要であるといえる. この他, 四つのシステムに共通していえることとして, 記号の前の終止表現, 助詞”と”の多義性の誤謬などはある程度改善されたが, 根本的な解決策を用いたというより翻 訳の coverage の広い对訳語を生成するといった程度の改善であるといえる。

以上を総合すると, (Choi and Kim 1996) 以降, 技術的には大きな变化は無く, 辞書や文法の 拡張やチュウニングだけで問題を解決しようとしたと判断される.

\section{6 結論}

\section{1 開発への提言}

各システムの翻訳結果を分析した結果, 次のような点が明らかになった.

- 韓国語と日本語との類似性, すなわち, 文の構造, 語彙などの 類似性に依存しすぎている

- 正確な分析に基づく翻訳になっていない

- 名詞はもちろん動詞においても日本語の漢字表記語をそのまま韓国語の漢字音に変換す るといった極めて単純な翻訳に依存している

- 固有名詞, 日本語の和語, カタカナ表記外来語などが辞書に登録されていない場合が多い

- 述部の翻訳において複雑な形態素の結合に十分対応できていない

- 日本語独特の造語法に十分対応できていない

- 状態/動作に関する区別など, 言語学的にはほぼ解決の糸口がつかめつつある問題に関し ても注意が払われていない音韻の縮約, 媒介母音の挿入, 述語の活用など, 韓国語の綴り に十分対応していない

- 動詞と名詞の多義性への配慮の欠如 
このような問題を解決するため次のような課題を提案する.

\section{短期課題}

(1) 辞書の拡張

主に外来語の表記を担当するカタカナ, 漢字で表記される固有名詞, 日本語の和語を そのまま韓国語の発音に機械的に変換するといった極めて単純な処理に依存せず，こ れらについては辞書に登録して正確な韓国語の対訳を生成すべきである. 実際の実験 結果, 未翻訳誤謬のほとんどは人名, 地名, 団体名などといった固有名詞の未登録によ り発生している. 特に, 最近では日韓機械翻訳機の使い道が WWW 情報の翻訳にまで 拡大していく傾向にあることを考えると, WWW で頻繁に用いられる語彙に対する用 語調査と登録が必要である.

（2）韓国語表記法に合った翻訳文の生成

韓国語は活用が多く, 分かち書きをする言語である.したがって, 活用や分かち書き愦 謬はユーザの翻訳結果の理解に大きな障害となり，時には意味上の誤謬まで生み出す 結果にもなり得る。このような韓国語生成技術はある程度確立されている。このよう な技術の積極的な導入が必要である.

(3) 日本語分析誤謬の解決

分析性能の向上は必ず解決しなけらばならない最も重要な課題である.これが不安な 状況でその後の多義性誤謬のための技法などは効果が得られないからである. 効用性 が立証された技法を利用して日本語分析の性能を向上させなければならない.特に, 主にひらかな文字列で表現される機能語部分の分析に力を注ぐ必要がある.

\section{中長期的課題}

（1） 大量の日韓対訳コーパスの構築

現在の日韓機械翻訳システムは一般の文法書と一般辞書から文法と辞書を構築する演 繹的 (deductive) な方法を採用して来た. したがって, 一般の文法書に記述されている 定型化された言語現象についてはある程度性能を発揮するが, 実際の言語生活で用い られる日本語に対しては対応しきれない面を数多くもつ.これは現在の日韓機械翻訳 技術の限界でもある。この限界を乗り越え，日韓機械翻訳技術を向上させていくため には実際の人間の言語を反映する大量の日韓対訳コーパスの構築が必要である. 大量 の日韓対訳コーパスから日本語と韓国語の類似性, 相違性についての分析と翻訳知識 の帰納的構築によりより実生活で用いられる日本語や韓国語の言語現象に機械翻訳が 対応できるようになるであろう。

（2）日韓翻訳知識自動獲得ツールの開発

人間による翻訳知識の構築は多くの費用と時間が必要であり, 構築された翻訳知識の 
図 4 単純定型文に対する多義性処理結果 (名品)

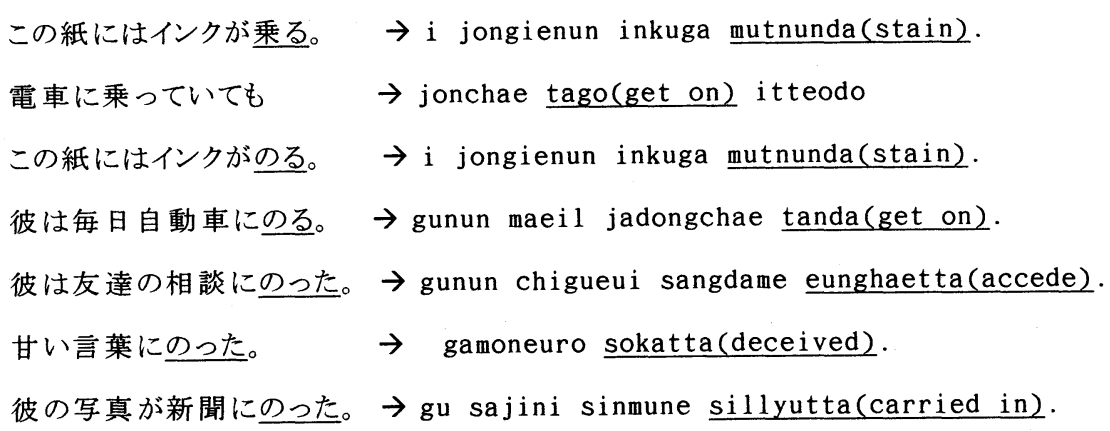

一貫性を見出すことも困難である。したがって, 大量の日韓対訳コーパスを用い翻訳 に必要な各種の言語情報を自動的に抽出できるッールの開発によりより客観的でパ ワーフルな翻訳知識の構築が必要である.

（3）日韓機械翻訳のための意味情報構築および活用

現在の日韓機械翻訳システムは形態素あるいは常用句のレベルで直接機械翻訳方式を 採用している. 意味の処理においては意味素性分類に基づく格構造あるいは連語情報 を用いた多義性の解消技法 (Park 1995) を採用しているが, 意味素性の分類, 日本語韓国語の単語間の意味範囲の違いなどについての研究が立ち後れており期待通りの結 果が得られていない. 多義性の処理について各システムが実際どれほどの処理能力を 持っているのかを把握するために「乗る」「のる」という動詞を例に実験した。その 結果を図 4に示す. 図 4でも見られるように定型的で単純な文構造ではある程度多義 性が解消されているように見える.しかし，実際のテキストでは全くといって良いほ どその機能を発揮していない.これは多義性の解消のための意味情報とその処理技法 が断片的で十分でないことを物語るものである.大量の日韓対訳コーパスを用い客観 的で一貫性のある意味情報の獲得と日本語-韓国語の単語間の意味範囲の違いを究明 することにより正確な意味分析と対訳語選定が可能な環境を作る必要がある.

\section{2 おわりに}

本技術資料では, 四つの商用システムを対象に直接翻訳実験を行った結果に基づきその翻訳 品質について評価した. その結果, 現在のシステムは, 片仮名, 日本語の漢語, 和語の韓国語への 単純音訳, 一対一の対訳語の選択などといったレベルでの翻訳であることが分かった. これは結 果的に現在のシステムが日韓の言語的類似性に頼りすぎていることを物語るものである.さら に, すでに応用可能な技術の導入にも消極的であることが分かった. 今後は両言語の類似性より 
両言語の相違点に焦点を当てるべきである.現在のシステムも入力テキストに関する何らかの制 限も設けず汎用として販売するよりは 4.2 の “Declarative Evaluation”で明らかになったよう に, 使用目的, 翻訳対象文の制限 (漢字表記が多く用いられる政治, 経済, 法律, 科学 関連 乾燥体 文書）などといった使用分野を特定すれば機械翻訳システムの利用環境を十分向上させること ができ，一般ユーザからも肯定的な評価を得ることができると思われる．このような翻訳品質お よび使用範囲に関する努力とユーザの便宜性を考虑した様々な機能とツールを支援するための 研究もおろそかには出来な課題の一つである. 商品化されたシステムの出現は市場からの技術改 善要求をフィドバックしながら技術の向上がはかれるという技術進化の一つの過程に位置する. 今回の調査結果を発展の過程から評価するなら, その間の進展について高く評価すべきである.

\section{参考文献}

Arnold, D. et al. (1993). "Evaluation : An Assessment." Machine Translation, 8, (2).

Choi, K. S. and Kim, T. W. (1996). “日韓機械翻訳システムの現状および分析.”言語処理学会 弟 2 回年次大会発表論文集, pp. 433-443.

Dijk, Bureau Marcel (1979). "Critical study of methods for evaluating the quality of machine translation." Final Report, Ingenieurs Conseils en Methods de Direction.

King, Margaret (1996). "Evaluating Natural Language Processing Systems." CACM, 1 (1).

Park, C. J. et al. (1995). “連語パターンによる日韓機械翻訳システムの構築とその評価.”日本 情報処理学会研究報告 95-NL-109, 情報処理学会.

White, J. S. et al. (1994). "The ARPA MT Evaluation Methodologies : Evolution, Lessons and Future Approaches." In Proceedings of the AMTA-94, pp. 433-443.

White, J. S. and O'Connell (1994). "Tutorial of Association for Machine Translation in the Americas." Cannada, OCt. 2.

井佐原均 他 (1996). “開発者の視点からの機械翻訳システムの技術的評価一テストセットを用 いた品質評価方法一.”言語処理学会誌, 3 (3).

\section{略歴}

金泰完： 1985 年韓国漢陽大学校大学院電子工学科修士課程卒業. 1998 年現在 韓国科学技術院電算学科博士課程. 1985 年 2 月より ETRI コンピュタ,ソフ トウェアー研究所, 自然語処理研究部勤務。機械翻訳, 自然言語処理, 知識 情報処理の研究に従事. 言語処理学会等の会員.

崔杞鮮: 1986 年韓国科学技術院電算学科卒業. 工学博士. 韓国科学技術院電 算学科助教授, 副教授を経て, 1998 年より韓国科学技術院電算学科教授. 1987-1988 年 NEC，C\&C Information Research Laboratories 招請研究員. 
1997 年 Stanford 大学, CSLI 訪問教授. 韓国語情報処理, 機械翻訳, 専門用 語, 認知科学, 多国語情報検索, 知識情報処理等の研究に従事. 韓国文化体 育部, 国立図書館, 文化芸術財団諮問委員. CPCOL, 言語処理学会 編集 委員. 現在 FIPA, TC6 議長.

(1997 年 10 月 16 日 受付)

(1998 年 4 月 10 日 採録) 